\title{
A sustainable city for the career woman
}

\author{
M. Goldman \\ English and Media Studies, Bentley University, USA
}

\begin{abstract}
Historically, cities have been friendly places for women, especially single women, and in cities like New York and Boston, women have outnumbered men. Women's movements, indeed feminism itself, owe their beginnings to the stimulus of the urban environment. Research shows that it is in cities that women begin to move up the career ladder. But, when women have children they often move to the suburbs because they and their spouses conclude that cities are poor places to raise children: they are dangerous and dirty, with poor schools and inadequate child care support systems. Once children arrive, women pick up most of the housekeeping and child care burdens. Research shows that women's isolation in the suburbs, distance from work, and the obligations of childcare cause them to leave the workforce or land on something called the "mommy track," now recognized as too often a road to career oblivion.

But what if the cities were liveable and clean, with parks for children to play in, with safe and inviting neighbourhoods, good schools and all of the community supports that can come with urban density? What if women could benefit from the synergies of living near their professional peers, or being near women with similar career goals and challenges?

Recent developments in urban planning for sustainability in the US, have and will have an impact on women's lives, especially career women with children for whom sustainable cities may offer the most clear path yet for successfully combining family and work. Also cities may become more sustainable in economic, social and environmental terms when women, building careers and raising families in cities, become part of the process as sustainable cities are developed.

Keywords: urban, city, lifestyle, family, career woman, gender, leadership, environment, nature, sustainability.
\end{abstract}




\section{Women and the city}

Cities have historically been friendly places for women, especially single women, and in cities like New York and Boston, women have outnumbered men. Women's movements, indeed feminism itself, owe their beginnings to the stimulus of the urban environment. As Sarah Deutch writes in Women and the City: Gender, Power, and Space in Boston, 1870-1940, the women of Boston changed "both the manners and the physical layout of the modern city," transforming Boston from a place "with no respectable public space for women, to a city where women sat on the City Council and met their beaux on the street corners." And in fact, Deutch contends, they succeeded in "breathtaking fashion, rearranging and redefining the moral geography of the city," and in so doing, they broadened the scope of their own opportunities. Even though there were limits to their success in shaping the city to make it friendlier to women, Deutsch makes clear the "crucial connections between gender, space, and power" [1].

In cities women begin to move up the career ladder. For example, The New York Times reported in a 1995 piece, "New York City Women Edge Closer to Men in Pay," that "the gender gap (in pay) had almost closed." In advertising and in the city's law firms, women, the Times article reported, were thriving. But while trumpeting the fact that men and women were working together as equals, the article concludes with a quote from Claudia Goldin, a Harvard economist, that, given the workload required for high level professional success: "If you have a wife, you can have both a career and a family, but not many women do" [2].

\section{Women leave the city}

When women have children, they often move to the suburbs because they and their spouses conclude that cities are poor places to raise children: they are dangerous and dirty, with poor schools and inadequate child care support systems. For these families, suburbia, in contrast to the city, promises home, community, and a clean, natural environment. But when their children are born, women assume most of the housekeeping and child care burdens. They find that their isolation in the suburbs, distance from work, and the obligations of child care cause them to leave the workforce or land on something called the "mommy track," now recognized as too often a road to career oblivion.

As Susan Seagert points out in "Masculine Cities, Feminine Subjects," this trend to connect the family/home to the suburbs has led some to see the suburbs as "feminine" and "domestic," while the city is "masculine" and "public." While Seagert points out that this is a largely "fictional" bifurcation, she also says that it unfortunately "finds its way into public policy and planning and into women's and men's sense of who they are." In addition, this view is especially burdensome for women whose suburban roles and status in the work world are "consistently underestimated" [3]. 


\section{The changing nature of work}

Unfortunately, this trend of moving families out of the city and into the suburbs comes at a time in the US when professional work is changing, requiring more interactivity and intensity - the kind of work that suits the city with its concentration of people and resources. Work today is more technological, global, environmentally sensitive, service oriented, and fast changing - reflecting the global reach of the internet and the "flat" rather than "hierarchical" structure of much of the workforce. The characteristics of those who will lead the work force are also different from the command and control approach of the past. Betsy Myers, who worked in both the Clinton and Obama administrations, in her recent book, Take the Lead, says the successful new leaders "tend to bring a very different dynamic to leadership, one that is collaborative, and team-centered, that thrives on connection, relationship, openness and cooperation with those who have different viewpoints and beliefs. It is leadership style that "engages" people [4].

Myers asserts that this leadership style is "more feminine" and inherently more compatible with an equal and diverse workplace. In the same vein, Donna Evans in "Room At The Top: Advancement And Equity For Women In The Business World," reviewing recently published research, concludes that "Generally women bring a different management style that is more inclusive and collaborative ... they build a "a diverse environment" . . . "where the best talent comes together, regardless of gender to affect business decisions and direction" [5]. In "The Female Leadership Advantage: An Evaluation of the Evidence," the authors conclude that "Women's leadership styles are more democratic than men's, even in organizational settings, possibly reflecting the special legitimacy problems that female leaders face if they attempt to take charge in a clear-cut, traditionally hierarchical manner" [6].

Companies acknowledge that this package of abilities makes money for the company. The 2009, McKinsey, "Women Matter," global survey on gender diversity highlighted the link between the characteristics of women leaders and organizational health [7]. McKinsey's 2010 "Centered Leadership" research found that many women bring an approach to leadership well suited for the challenges that major organizations face today [8]. Evidence highlighted by McKinsey research also shows that increased representation of women in executive ranks leads to increased corporate and financial results [9]. It is a finding that Catalyst researchers also substantiate [10-13].

Despite these facts, analysts agree that not enough women are moving through the career pathways to arrive at positions of leadership, and a Mercer study also highlights the problem [14]. Statistics back this up. Statistics from Catalyst in 2011 show that women account for 46.7 percent of the US labor force and that 51.5 percent of these working women hold management, professional and related occupations. Women hold only 15.4 percent of corporate office positions, 14.8 percent of board, and 2.4 percent (or 12) of chief executive title in Fortune 500 companies [11]. In other words, women isolated in the suburbs and 
on the mommy track are missing in action at precisely the time their types of skills are needed.

Remedies to address this leadership gap range from a focus on providing work/family balanced environments; workplace "flexibility"( Catalyst points out that three quarters of all requests for flexible working over the past twelve months of 2010 have been from women.); the development of informal networks; provision of role models and mentors; and providing managerial and diversity training $[12,14]$.

\section{Women's space}

Rarely, in these discussions of women and business, does the issue of women's space come front and center as a barrier to women's advancement, despite the evidence that women, once they are married and have children leave the cities and accept jobs that are closer to home, even though this choice may cut them off from the best opportunities for advancement. When one considers how collaborative and interactive the workplace of the future looks, and what leadership of these modern companies looks like, and contrasts this vibrant professional landscape with the isolation and lack of community of women who live in the suburbs of the US, it is not a stretch to conclude that women who live in these environments are cutting themselves off from the opportunities of the modern workplace.

One can get a close look at the consequences for this situation of women through the 2001, "Mass Action for Women Audit," conducted by the Massachusetts Action for Women and the Center for Women in Politics and Public Policy at the University of Massachusetts, Boston. This audit "gathered information on the health, educational, economic, and political status of women and in their cities/towns and regions." Interviews and group meetings identified the greatest concern of women living outside the city to be concern for "sustainable financial security." The audit noted that "financial security gives you choices. Our goal is economic empowerment and to galvanize women across all lines - something that is achievable, sustainable" [15].

However, in trying to help women reach that goal and be more connected to their communities, the interviewers found that the main barriers were that geographic barriers were hard to connect across (lack of transportation was singled out); women face multiple pressures that kept them isolated; women did not have time. As one of the interviewers, Pam, wrote:

One of the issues that I see is that today's women, in all walks of life, are becoming more isolated. They have more and more stress on them. They have their work responsibilities and their home responsibilities. And getting them to commit to long term involvement, I think, is a real challenge - to get women who, because it might sound interesting to them, but they're torn in so many places that they can only be - when they leave work, they have to be home. They have day-care issues, whatever else. And I see it not just in the audit project, I see it in all the work that I'm doing - is getting women to feel like they're involved and part of what's going on in their community [15]. 
In contrast, that same Audit identified different barriers for women in the city of Boston, most notably the lack of affordable housing, good schools, safe environments, and political empowerment. But the Audit also noted that "Boston and the surrounding communities are the most concentrated population centers in the state. They are rich with women's organizations and activism." They noted increased day-care capacity in Cambridge, the distribution of financial information to women in Jamaica Plain, and more career specialists. One woman in her twenties said that women were seeing a range of career opportunities:

"I think that people, women who are my age are starting to see, are coming into a field and different careers that are "non-traditional" like business and science. And it doesn't feel like they're pioneers anymore. It's something, it's a given to them" [15].

Some women and their families are taking note of the advantages of city living for career development. In "Family Gentrifiers: Challenging the City as a Place Simultaneously to Build a Career and to Raise Children," the author, Lia Karsten, argues that while suburbanization by families with children "can be considered as a dominant factor in determining the structure of a city's population; due to urban "restructuring" programs, a "modest counter process can be observed." In the city of Amsterdam for example, Karsten notes that some families who could afford to buy a house in the suburbs decided instead to stay in the central areas of the city. In so doing, they formed a relatively new category of gentrifiers: middle-class families with children. In this article, they are identified as 'yupps': young urban professional parents. They combined the next step in their life cycle - having children - with continuing their career and their preference for an urban lifestyle. Karsten also believes that as a result of their choice to live in the city, relationships are changing: "in a class-specific context, changing gender relations lie at the root of family gentrification, resulting in the construction of new male and female identities" [16].

\section{The sustainable city}

While there is are some cities that do meet, at least in some respects, the needs of a sustainable women/family friendly urban world and while modern urban planners have identified cities as spaces of opportunity for women, where they can earn income and power, create strong social networks for mutual support and stimulation, and have more mobility and freedom, a growing body of evidence suggests that most cities remain too unfriendly to women and their families, limiting their options and creating boundaries that they cannot cross. Obstacles include lack of safety, high costs, especially of housing, poor schools, pollution, lack of open spaces, and parks.

Fortunately, making the city more family friendly/career friendly coincides with making a city more sustainable and there is also certain urgency in moving forward. In 2010, according to the statistics of the Siemans Corporation, 82 percent of Americans lived in cities; by 2050, it will be 90 percent. Cities are responsible for around two thirds of the energy used, 60 percent of all water 
consumed and 70 percent of all greenhouse gases produced worldwide. In this respect the US is little different than the rest of the world. So, as more and more of the world's population lives in urban environments, putting pressure on natural resources, infrastructure, land and water uses, housing, transportation and other inter-related factors, we are faced with many questions relating to quality of life, urban regeneration, and sustainability. Such questions are particularly acute for women, as they seek to provide their families with a clean, healthy, safe environment, access to safe outdoor spaces, educational opportunities, and rich cultural opportunities at the same time that they try to maintain personal career momentum and self-fulfilment. Recognizing the need to address these environmental problems, the United Nations in the early 1980s created the World Commission on Environment and Development (the Brundtland Commission) to study the impact of human activity on natural resources and the subsequent effect on economic and social development. The commission's report, released in 1987, identified sustainable development as that which "meets the needs of current generations without compromising the needs of future generations." Later, "triple-bottom line" accounting came into being to evaluate and support sustainable development. This accounting system may be used to aid community planning and decision-making processes by taking into account environmental, social, and economic impacts. In the same vein and using data from the Mountain Association for Community Economic Development (MACED): Hart Environmental Data, one analyst proposes that the sustainable community needs the following:

- $\quad$ Economy - Economic activity should serve the common good, be selfrenewing, and build local assets and self-reliance.

- Ecology - Humans are part of nature, nature has limits, and communities are responsible for protecting and building natural assets.

- $\quad$ Equity - The opportunity for full participation in all activities, benefits, and decision-making of a society [17].

In addition many emphasize the transformative power of technology to make a city sustainable. "The best of these ecosystems will be cities and towns that combine a university, an educated populace, a dynamic business community and the fastest broadband connections on earth. These will be the job factories of the future" so argues Blair Levin, who runs the Aspen Institute's Gig.U project, a consortium of 37 university communities working to promote private investment in next-generation ecosystems: "The countries that thrive will be those that build more of these towns that make possible "high-performance knowledge exchange and generation." (As quoted in Friedman [18].)

The economic argument for sustainability, as well as the social one, derives from a number of factors that are endemic to city life and are why many argue that cities are the growth engines of the future. Fundamentally, cities bring people into close proximity to one another and that is a powerful source of creativity and productivity. Cities magnify people's strengths Edward Glaeser in Triumph of the City argues, because ideas spread more easily in dense 
environments [19]. "If you want to compete in a global marketplace, it really helps to be near a downtown" (as quoted in Brooks [20]).

There are other advantages of cities. International economist, Rakesh Mohan, speaking at the 2007 Global Urban Summit sponsored by the Rockefeller Foundation, referenced cities" "immense efficiency," observing that it is no accident that corporations large and small, banks and investment houses, universities and research laboratories, and specialized manufacturing all congregate, in overwhelming measure, in cities. The proximity of roadways, rails, ports, and airports in urban areas reduce time, travel, and energy costs in a way that rural areas simply cannot match. On a human level, cities satisfy the universal need for face-to-face contact to foster new products, processes, and intellectual capital. Cities are great magnets for the world's best thinkers and innovators. Inventors disproportionately cite ideas from others who live physically close to them [21]. Thus, the city of Boston is sponsoring the construction of an "innovation" district, so that innovators can feed off the propinquity of others like them to come up with new projects. Moreover, as Glaeser argues, the best cities attract and properly allocate human capital and should be judged by these standards, rather than their architecture or institutions $[19,20]$. In this environment, for example, women would benefit from the synergies of living near their professional peers, being near women and men of with similar career goals and challenges.

Today that goal is not yet achieved, especially as regards women. A series of essays in Gendering the City: Women, Boundaries and Vision of Urban Life, edited by Kristen Miranne and Alma Young, concludes that "The field of urban studies has long reflected a gender bias in both the construction of theory and the avoidance of essentials that directly address women's lived experiences" [22]. Commenting on the same problem, Joel Garreau, in Edge City, Life on the New Frontier, observes that women's expectations about career and family life have changed and that power shifts in relationships are reflecting those changes. $\mathrm{He}$ urges that urban structures need to "consider the relations of the genders to home and to work and to their aspirations in terms of lifestyle" [23].

\section{The natural environment of cities}

While cities might make the best argument for "sustainability "in terms of economic development, or as some call them, "economic ecosystems," they need also to meet environmental concerns, if they are to be truly "sustainable" both in terms of the natural world and the human one. And, once we start paying attention to how access to our land and water, to parks and playgrounds and pay attention to health, safety, recreation, and the ability of families to raise children in an urban environment, we can also address professional women's often limited career choices once they enter motherhood. Once those quality of life issues are addressed, the city can become a place to build a home and a career, and a place where both are sustainable. If, however, families are forced to leave the city, the city becomes less sustainable, and city planners are more likely to 
ignore the importance of easy access to parklands, transportation, public schools, play spaces, libraries, and after-school programs.

Sustainable cities need to go one step further. Less attention has been paid to how urban residents - soon to be the largest part of the global population — can develop an ecological connection to natural places such as parklands, waterfronts, riverbanks and other open spaces. Professor Frank Gaughan of Hofstra University observes that, 'Unfortunately, efforts to 'green' city spaces or to effect environmental justice in urban areas are likely hampered until citizens feel an ecological connection [24], or what Aldo Leopold (one of the most renowned figures in conservation, wildlife ecology, and environmental ethics), calls a "striving for harmony" with the land" [25]. One could argue that women - and their families - are key to cultivating that kind of ecological connection and that women need to take on a more front and center role in shaping urban spaces.

\section{The future}

Women and the sustainable city need each other. Women need to be part of the new economy which is going to depend on the density, interactivity, synergy and convergence of skills that cities offer. It is easiest in the city to be employed in one of the better-paying professions, and, if one is married, for both members of a professional couple to be adequately employed. If enough such couples were attracted back into the city, it would provide the tax base to support the social programs that eroded with the middle- class flight to the suburbs. As Eli Ginzberg, chair of the National Commission for Employment Policy, has argued, "The new trends to later marriages, low births, and the increased career interests of educated women provide the city with an opportunity to attract and retain professional couples, both of whom hold good jobs and are career oriented" [26].

Moreover, as Jo Freeman in "Women and Urban Policy," contends, our cities can be great arenas for experimentation in life-styles not based on the traditional sex-role allocations. They can be places where women and men can live more equally without paying a price for deviancy and where all persons can fulfil more efficiently and productively the obligations of their work and private lives without having constantly to juggle serious conflicts. Freeman says that to have the programs and the policies to make this possible "requires that our decision makers shed both traditional conceptions of the family and restricted ideas of appropriate sex roles. It requires acknowledging the person as the basic unit of society, with both a private and a productive life, and creating the support structure and the employment possibilities necessary to make this a reality" [26]. And, for career professionals, if they are going to be leaders, using the skills of collaboration, team work and the like that will define the new economies leaders; they are going to have to be where the action is. So women need cities-and they need cities that support their personal and professional needs.

Cities need women. Women can bring the qualities of environmental and personal investment that will make them sustainable. Is there a greener gender? Studies show that women are more likely than men to support environmental 
causes through voting, activism, and consumer choices. The work of Jane Jacobs illustrates the difference that women might make once they commit to the city. Through her life, she fought to alter the way in which city development was approached. By arguing in her seminal book, Death and Life of Great American Cities, that cities were living beings and ecosystems, she advocated ideas such as "mixed use" development and bottom-up planning. She suggested that over time, buildings, streets and neighborhoods function as dynamic organisms, changing in response to how people interact with them. She explained how each element of a city - sidewalks, parks, neighbourhoods, government, and economy - functions together, synergistically, in the same manner as the natural ecosystem. This understanding helps us discern how cities work, how they break down, and how they could be better structured. Pondering why men and women's voices were heard differently on the subject of city building, Jacobs noted that women think about things close to home - street, neighbourhood and community. They more easily recognize the big difference small things can make [27].

A number of urban planners and thinkers have also argued that women need to part of the thinking as sustainable cities are developed. Hillary Brown of New Civic Work, a consulting group in New York City, suggests: "The public sector seems better positioned to benefit from women's styles of leadership." She continues: "There's an affinity that women have with sustainability - they're as interested in the process as the product. But it isn't about gender - it's about a sensibility. It's about empathy with the earth as a living process" [28]. The national organization, Women for Sustainable Cities, takes much the same tack, while reinforcing the need to educate women to fulfil this goal.

As we plan for the future then, we can envision an interactive interplay between the city and its citizens, where the relations of men and women to their homes and work reflect their aspirations and lifestyles - a place where equality and respect for the environment coexist and mutually reinforce one another and where women can have careers and families while creating a dynamic, green, healthy urban space.

\section{References}

[1] Deutsch, Sarah, Women and the City: Gender, Power and Space in Boston, 1870-1940, Oxford University Press: New York, 2000.

[2] Redburn, Tom, "New York City Women Edge Closer to Men in Pay," New York Times, 02 Feb. 1994.

[3] Seagert, Susan, Masculine Cities, Feminine Subjects: Polarized Ideas, Contradictory Realities," Signs, 5, 3, pp. S96-S111, 1980.

[4] Myers, Betsy, Take the Lead, Atria: New York, 2011.

[5] Evans, Donna, "Room at the Top: Advancement and Equity for Women in the Business World," National Civic Review, 100, 2, pp. 62-64, 2011.

[6] Eagly, Alice H., Johanssen-Schmidt, Mary C., "Leadership Styles for Men and Women," Journal of Social Issues, 57, pp. 781-797, 2001.

[7] McKinsey \& Company, "Women Matter 2010," October 2010. 
[8] McKinsey \& Company, "Centered Leadership." 2010.

[9] Desvaux, Georges, Devillard-Hoellinger, Sandrine, Meaney, Mary C., "A Business Case for Women"' McKinsey Quarterly, pp. 1-6, September 2008.

[10] Soares, Rachel, Marquis, Christopher, Lee, Matthew, "Gender and Corporate Social Responsibility: It's A Matter of Sustainability." Catalyst, November 2011.

[11] Carter, Nancy, Silva, Christine, "Pipeline's Broken Promise," Catalyst, Feb. 2010.

[12] Carter, Nancy, Silva, Christine, "Women in Management: Delusions of Progress," Catalyst, March 2010.

[13] Troiano, Emily V, "Workplace Trends: Today's Decisions, Tomorrow's Successes," Catalyst, September, 2008.

[14] Mercer, "Most Employers Lack a Strategy for Developing Women Leaders, Mercer Survey Shows," March 27, 2011.

[15] Massachusetts Action for Women and the Center for Women in Politics and Public Policy, Massachusetts Action for Women Audit, University of Massachusetts: Boston, 2001.

[16] Karsten, Lia, " Family Gentrifiers: "Challenging the City as a Place Simultaneously to Build a Career and to Raise Children," Urban Studies, 40, pp. 2573-2584, November 2003.

[17] Smith, Mark K,) "What is a Sustainable City?" from "Sustainable Communities and Neighborhoods. Theory, Policy and Practice," The Encyclopaedia of Informal Education. 20, Sustainable City Network, Inc., Dubuque, IA. Powered by BLOX Content Management System from TownNews.com. 2012.

[18] Friedman, Thomas, "So Much Fun. So Irrelevant," New York Times. Jan 3, 2102.

[19] Glaeser, Edward, Triumph of the City, The Penguin Press: New York, 2011.

[20] Brooks, David, "The Splendor of Cities," The New York Times. Feb.7, 2011.

[21] Mohan, Rakesh, speech at the 2007 Global Urban Summit, Rockefeller Foundation, Bellagio, Italy, 2007.

[22] Miranne, Kristen, Young, Alma, eds., "Gendering the City: Women, Boundaries and Visions of Urban Life, Rowman, Littlefield, 2000.

[23] Garreau, Joel, Edge City, Life on the New Frontier, Anchor: New York, 1992.

[24] Gaughan, Frank, "ASEH Panel/Paper Proposal Aldo Leopold in Urban Settings," Personal Correspondence, Email, June 29, 2011.

[25] Leopold, Aldo, A Sand County Almanac and Sketches Here and There, New York: Oxford University Press, 1949.

[26] Freeman, Jo, "Women and Urban Policy" Signs, 5, pp. S-4-21, 1980.

[27] Jacobs, Jane, Death and Life of Great American Cities, 1961, Modern Library Edition: New York, 2011.

[28] Gould, Kira, Hosey, Lance, Women in Green: Voices of Sustainable Design, Ecotone, 2007. 